\title{
THE IMPLEMENTATION OF STATE ENVIRONMENTAL POLICIES AT THE NATIONAL, REGIONAL AND LOCAL LEVELS IN UKRAINE
}

\section{Petretska N. I.}

\section{INTRODUCTION}

Today the tendency of rapid development of both international environmental law and national environmental legislation has been established in the world; it is accompanied by an unprecedented phenomenon - the mutual "flow" of advanced environmental ideas within the framework of national and international environmental law.

The human right to a clean environment in the constitutions of modern states is the legal basis for the consolidation of the ecological function of the state. Preserving the environment for the present and future generations is seen as a shared responsibility of the state, civil society and man in modern law theory and constitutional practice. The right to a safe environment which is based on the natural legal doctrine, expresses the social purpose of environmental law. This doctrine reflects the idea of orienting the entire environmental policy of the state towards protecting the life and health of its citizens by means of guaranteeing a safe and quality environment.

Ever since Ukraine became independent, the issue of forming state environmental policy emerged in the context of overcoming the consequences at the Chernobyl Nuclear Power Plant after the disaster happened. The other problems such as: industrial pollution, waste treatment, agrarian sector reform, the control of emissions of harmful impurities and substances into the atmosphere, water and land pollution have not been of great importance. Hence, the right to environmental safety has been neglectful for a long time.

State environmental policy is an activity of state bodies aimed at ensuring the constitutional right of everyone to a safe and healthy environment and compensation for the harm caused by a violation of this right. It can also be talked about implementing Environmental policy within enterprises or organizations ${ }^{1}$.

L. Vasylchuk distinguishes several stages in the development of the right to environmental safety as an integral part of environmental policy. They are:

1. The establishment of the system of realization of the right to a safe and healthy environment in Ukraine 1991-1993.

2. The nuclear disarmament of Ukraine - from 1994 until June 28, 1996.

${ }^{1}$ Національна екологічна політика: міністерство екології та природних ресурсів. URL:https://menr.gov.ua/timeline/Nacionalna-ekologichna-politika.html. 
3. The Constitutional recognition and consolidation of the right to a safe and healthy environment in Ukraine from 28 June 1996 to 22 February 2014.

4. The latest stage in the realization of the right to a safe and healthy environment in Ukraine connected with the process of integration to Europe, has started since February 22, 2014 and continues to this day ${ }^{2}$.

The sharp exacerbation of environmental problems in Ukraine is caused by a number of political, socio-economic, technical, technological, organizational and other factors. The main ones are: the ecologically unbalanced extensive development of productive forces and consequently, the exhausting exploitation of natural resources, the irrational structure of the economy in terms of ecology; the ignoring of the environmental imperatives by almost all manufacturers; the technical and technological, and organizational backwardness of social production and underdevelopment of environmental infrastructure; low rates of introducing the economic and legal mechanism for the rationalization of environmental management and implementation of environmental measures; the lack of regulatory and methodological support of legislative acts in the activities of regional and local authorities ${ }^{3}$.

Modern scientists distinguish three main levels of implementing environmental policy: global, national and local ones. However, as noted by A. Lazor, it is necessary to recognize such levels of the implementation of environmental policy: local - the level of an enterprise / an organization; the level of an administrative district, a city; the regional level; subnational the level of several regions; national - the state level; stat-to-state - the level of several states; global - the level of the planet ${ }^{4}$.

\section{The implementation of Ukraine's national environmental policy: pros and cons}

The national environmental policy is formed by the Ministry of Ecology and Natural Resources. Until recently, it has been the Ministry's responsibility to simultaneously develop and implement environmental policy. Currently, as part of public administration reform, the Ministry is planning to focus on expert, analytical work, which will be related to developing solutions in environmental protection activities, however, their

\footnotetext{
${ }^{2}$ Реалізація права на безпечне для життя і здоров'я довкілля в Україні: монографія. Л.Б. Васильчук, Ю.М. Бисага. Ужгород, 2019. 208 с.

${ }^{3}$ Костицький В.В. Екологія перехідного періоду: право, держава, економіка (економікоправовий механізм охорони навколишнього природного середовища в Україні). К., ІЗП і ПЗ, 2003. $772 \mathrm{c}$.

${ }^{4}$ Лазор О.Я. Адміністративно-правові засади державного управління у сфері реалізації екологічної політики в Україні. Автореферат дисертації на здобуття наукового ступеня доктора наук з державного управління, К., 2004., ст. 8-9.
} 
direct implementation will be entrusted to various state agencies, services or local authorities ${ }^{5}$.

It is important to briefly delineate the specifics of the notions of state regulation and public administration in Ukraine, since environmental policy is a separate area of activity of the state and public administration. Public administration is an activity aimed at the implementation of laws and other regulations through the use of various forms of the organizational influence on social phenomena and processes. Almost all spheres of human life are the object of managerial relations, and the determining principle of this activity is subordination. In its content, the notion "public administration» makes use of administrative influences, that is, direct communication methods, in contrast to state regulation, which provides for the implementation of comprehensive measures in the field of environmental policy with methods of direct communication. In contrast, state regulation involves the implementation of integrated measures in the field of environmental policy for the purpose of streamlining them, establishing common norms and rules of public behavior for protecting the animate and inanimate nature of the environment, the population's health and life, organizing and maintaining the rational use and reproduction of natural resources. Provided the functioning of state regulation is effective, there is the need for direct intervention of the state and its institutions in the activities of environmental structures ${ }^{6}$.

That is why the development of fundamental principles of state environmental policy in terms of ensuring environmental safety is largely complicated by the heterogeneity and ambiguity of approaches to the identification of the content of the latter. For example, in the specialized literature, environmental safety is interpreted in several conceptual meanings:

a) the protection of humans and the environment against emergencies;

b) the condition of preserving human health and ensuring a sustainable socio-economic development;

c) the guarantee of preventing ecological catastrophes and accidents;

d) the balance of developing ecosystems ${ }^{7}$.

There is a high risk of natural and man-made emergencies in Ukraine. In Ukraine there are 23767 potentially dangerous enterprises and other objects, yet accidents at each of them can cause emergencies of technogenic and natural character at the state, regional, local and object levels. Up to 300

\footnotetext{
${ }^{5}$ Національна екологічна політика: міністерство екології та природних ресурсів. URL:https://menr.gov.ua/timeline/Nacionalna-ekologichna-politika.html.

${ }^{6}$ Лазор О.Я. Адміністративно-правові засади державного управління у сфері реалізації екологічної політики в Україні. Автореферат дисертації на здобуття наукового ступеня доктора наук з державного управління, К., 2004., ст. 8-9.

${ }^{7}$ Андрейцев В.І. Політика. Інновації. Приватизація. Еколологічна безпека. Право. К. 1996, C. 5-6.
} 
natural and man-made disasters are recorded annually, leading to the loss of human lives as well as major economic loss ${ }^{8}$.

Environmental security relationships are closely linked to the rational and efficient use of natural resources, the protection of the environment, the use of environmentally hazardous sites and objects, and this determines the complexity of the content of the concept of environmental safety, which includes: a) a certain state of a natural object (security of nature) and b) the system of guarantees provided by the state to its citizens which ensure normal daily activities of people ${ }^{9}$.

When forming the basis of state environmental policy in terms of legal support for environmental safety, it is advisable to take into account the fact that the current environmental legislation of Ukraine, as the legal criteria for a safe environment, provides for special standards of environmental safety:

a) the maximum permissible concentrations of pollutants in the natural environment;

b) maximum permissible levels of acoustic, electromagnetic, radiation and other harmful effects on this environment;

c) the maximum level of permitted contaminants in food.

It is obvious that the first two standards characterize the quality level of external environmental safety of a person, whereas the third one indicates its internal security. It is clear that this legislative model leads to a somewhat broadened understanding of a safe environment, within which environmental safety must be ensured ${ }^{10}$.

Contemporary environmental policies, both at the national and regional levels, are developed and implemented under tense political conditions, which are caused by various political goals and interests of agencies, and this often leads to conflicts between individuals. There are situations in which it is extremely difficult to find political consensus between environmental authorities and environmentalists, whose interests are often lobbied by relevant agencies and local governmental and non-governmental institutions. This, in particular, concerns the utilization of natural resources of public use, the distribution of economic requirements and costs, the responsibility for the future environmental consequences of an activity (or inactivity), etc ${ }^{11}$. The issue of environmental safety is gaining priority at the regional level. In the near future, ecology will determine the norms and lifestyle of society.

${ }^{8}$ Про Основні засади (стратегію) державної екологічної політики України на період до 2020 року. Закон України від 21.12. 2010. № 2818-VI. Відомості Верховної Ради України. 2011. № 26. Ст. 218.

${ }^{9}$ Екологічне право: підручник. За ред. А.П.Гетьмана. Х.: Право. 2014. С. 295.

10 Андрейцев В.I. Політика. Інновації. Приватизація. Еколологічна безпека. Право. К. 1996. С. 5-6.

11 Заржицький О.С. Актуальні проблеми правового забезпечення екологічної політики України (теоретичні аспекти). Монографія. Д.: Національний гірничий університет, 2012. $200 \mathrm{c}$. 
The excessive concentration of environmentally hazardous establishments, out-of-dated and ineffective environmental protection equipment at the final stages of technological chains, the reliability of technical systems and low qualifications of personnel at enterprises with a high level of environmental risk, and, finally, the issue of ensuring environmental safety of conversion, all of these can cause social and political tension ${ }^{12}$.

For years, environmental problems in Ukraine have not been solved by a specially created organism called the state. It may not suffice to say that everything depends on the person, if at every step they are offered «for convenience» to use means which are far from being environmentally friendly. By the way, taxes are paid for these harmful means to the state budget, both by the producer and the consumer. The question rises whether it is feasible to replenish the state budget in this way and then use these funds to solve environmental problem. This is, of course, a very profitable business, since three times less money is allocated for protecting the environment in the state budget in comparison with the costs received from the environmental tax. This is the so-called socialist «residual principle», which is still heavily used in budget planning.

All this is explained by many scientists as a transitional period in Ukraine after its independence was gained. It is a very convenient term for use in the post-Soviet countries, because, as one of French researchers points out, different authors characterize it differently. In particular: the transition from one type of political regime to another; the systematic reconstruction of social structures; changes occurring in the economic sphere; accompanied by some determinative criterion, this concept often indicates that political and economic systems are being reconstructed compared to Western countries ${ }^{13}$.

Freedom House contracts independent researchers from academia, journalism, and civil society for each country to draft the country reports and make the initial scoring. The Nations in Transit annual report researchers score the countries on a scale of 1 to 7 in seven categories: National Democratic Governance, Local Democratic Governance, Electoral Process, Independent Media, Civil Society, Judicial Framework and Independence, and Corruption. Category scores are based on a detailed list of questions available here. These category scores are straight-averaged to create a country's "Democracy Score" on a scale of 1 to 7, with 1 being the most democratic, and 7 the least.

Their conclusion about Ukraine in 2013: «Far-right extremism represents a threat to the democratic development of Ukrainian society. The brief provides an overview of the activities and influence of the far right,

\footnotetext{
12 Заржицький О.С. Актуальні проблеми правового забезпечення екологічної політики України (теоретичні аспекти). Монографія. Д.: Національний гірничий університет, 2012. $200 \mathrm{c}$.

${ }^{13}$ Фріб М. Як осмислити посткомунізм? Політична думка. 1997. № 4. С. 109-110. 186
} 
differentiating between groups that express radical ideas but by and large operate within a democratic framework and extremist groups, which resort to violence to influence society» ${ }^{14}$.

As of 2018, Ukraine, according to Freedom House is partly free ${ }^{15}$. Regrettably, the status of a transitional state for Ukraine is obviously beneficial for persons holding positions in the ministry. Hence, the irrational «enrichment» of the state budget, mentioned above, costs its citizens a low standard of living, poor health, which is a consequence of violating the right to a safe and healthy environment. Obviously, the status of a transitional state can last for decades, provided there is no strategy for the development of the branches of the state on the basis of the rational management of nature.

Contemporary environmental policy at the national level is rather disappointing. Fight against corruption is likely to be the biggest tragedy for Ukraine. It is impossible to improve the state of the economy, let alone global environmental problems, without being unaware of the rational use of funds, which are written off for obscure and unprofitable purposes of the society.

At the same time, each country, adopting its national strategy of sustainable development, transforms them according to the specific conditions. The implementation of the principles of sustainable development requires an appropriate public management in all sectors of the economy, at the levels of governance against the background of considerable fines and the effectiveness of laws. Such conceptual approaches should envisage the transformation of all types of education and the formation of ecological culture of the population; the change of communicational and informational, political, economic, social spheres according to the priority of interests and needs from local communities to the state as a whole; the use of environmental tax only for stabilizing and solving environmental problems; the proceeding to a new level of information potential of environmental protection and nature management; the metrological and in accordance with its and world scientific achievements, the harmonized regulatory support for the state, trends, quality of the environment and drinking water, food, the population's diseases from the combined action of food additives, industrial allergens, the evolution of antibiotics and drugs, etc ${ }^{16}$.

To the most important problems that have transformed from the national into the global ones in nature belong the problems of environmental safety and environmental protection. In The Main Principles (strategies) of the State Environmental Policy of Ukraine for the period up to 2020 there have been established the root causes of Ukraine's environmental problems:

\footnotetext{
${ }^{14}$ URL:https://freedomhouse.org/report-types/nations-transit.

${ }^{15}$ URL:https://freedomhouse.org/report/freedom-world/2019/ukraine.

${ }^{16}$ Скрипчук П.М., Строченко Н.І., Вега А.Ю. Соціо-еколого-економічні засади природокористування: інновації, інвестиції та механізм реалізації. Монографія під редакцією Скрипчука П.М. Рівне: НУВГП, 2014. 454 с.
} 
- the inherited structure of the economy with a predominant share of resource- and energy-intensive sectors, whose negative impact was exacerbated by the transition to market conditions;

- the depreciation of the fixed assets of industrial and transport infrastructure;

- the existing system of public administration in the field of environmental protection, regulation of the use of natural resources, the lack of clear delineation of environmental and economic functions;

- the poorly formed institutions of civil society;

- he lack of understanding in society the priorities of environmental protection and the benefits of sustainable development;

- non-compliance with environmental legislation ${ }^{17}$.

As a matter of fact, currently, the priorities in environmental policy, determined in the Draft Law of Ukraine «On the Main Principles (Strategy) of State Environmental Policy in Ukraine for the Period up to 2030», are being developed strategically. However, the proposals from the Ministry of Nature to the Ukrainian Parliament to significantly increase fines for environmental damage will not improve the environmental situation. At the beginning of our research, it has been noted that the financing of environmental needs from the state budget relies on «the residual approach». It means that environmental security funding receives one-third less money from environmental taxes collected.

Taking into account the Draft Law on Environmental Policy by 2030, it is becoming quite clear that there will be no suprapositive changes in improving the environmental situation in Ukraine. The introduction of an ecosystem approach to sectoral policies and improvement of the system of integrated environmental management is of particular importance. The endorsement of the strategy is challenging, as it should be admitted that there is the need for the integration of environmental policy with other policies, as well as for the mandatory consideration of the environmental component when developing and approving state planning documents and in the process of decision-making related to conducting economic activities that can have a significant environmental impact. After all, at the legislative level, such norms have already been established. The problem lies in the mechanism of implementing this strategy.

The introduction of environmentally safe, resource- and energy-saving technologies, the development of renewable energy sources, the utilization of intangible natural resources occur in Ukraine asystematically. Studying

${ }^{17}$ Про Основні засади (стратегію) державної екологічної політики України на період до 2020 року (Затверджено Законом України від 21 грудня 2010 року № 2818-VI. Відомості Верховної Ради України. 2011. № 26. Ст. 218. URL: http://zakon0.rada.gov.ua/ laws/show/2818-17. 
foreign experience is extremely important. The economic component in state environmental policy is central.

Environmental issues cannot be tackled in isolation from global environmental issues caused by anthropogenic impacts: drinking water problems; pollution of the oceans by sewage, petroleum products, debris; the protection of the ozone layer; soil erosion and contamination; massive deforestation and no restoration of forests; the decline in flora and fauna species; freshwater pollution in rivers, lakes and other reservoirs; the destruction of fishery resources; the irrational use of natural resources; global warming.

\section{The implementation of Ukraine's state environmental policy at the regional and local levels}

Admittedly, one of the priorities of the state regional policy, along with improving material, financial, informational, personnel and other resource support for the development of the regions, promoting the exercise of powers of local governments is also the creation of an effective environmental protection system by taking into account the ecological componentin the strategies of regional development, the estimation, equalization and reduction of technogenic and ecological environmental load in the regions ${ }^{18}$.

According to The Law of Ukraine «On the Principles of State Regional Policy», state regional policy is understood as a system of goals, measures, means and concerted actions of central and local executive bodies, local selfgovernment bodies and their officials that are there to ensure a high quality of life of people throughout Ukraine taking into account the natural, historical, ecological, economic, geographical, demographic and other features of the regions, their ethnic and cultural identity ${ }^{19}$.

The implementation of the state regional policy is carried out on the basis of a system of interrelated documents based on the Strategy of development of Ukraine, the General scheme of planning the territory of Ukraine, the regional and local planning schemes.

The importance of territorial planning of areas is set out in the State strategy for regional development for the period up to 2020, approved by the Cabinet of Ministers of Ukraine from August 6, 2014, Decree No. 385, which states that the proper planning of territories shall contribute to the improvement of regional investment and innovation infrastructure; shall ensure the formation of the favorable investment climate, a positive investment image and the promotion of the investment opportunities of the regions of Ukraine in the foreign market; shall contribute to the introduction of various instruments and mechanisms to stimulate local economic development, the creation of new

${ }^{18}$ Про засади державної регіональної політики. Закон України від 05.02.2015 p. № 156-VIII. Відомості Верховної Ради України. 2015. № 13. ст. 90.

${ }^{19}$ Ibid. 
business that focus on local sources of raw materials, meet the needs of the internal market; shall facilitate the implementation of projects aimed at improving the level of socio-economic development of border areas, improving their ecological state, building border infrastructure, developing tourism and so on. The European Union Strategy for the Danube Region sets out general guidelines for territorial planning and states that transport infrastructure has a positive impact on the development of the region, but in the absence of proper planning, it can have a negative impact on the diversity of species as well as on the quality of air and water ${ }^{20}$.

Due to the lack of detailed planning, a number of economic operations are not carried out, which in turn has affects the attraction of foreign investments that would contribute to the flow of funds to the state and local budgets, which would favour the socio-economic development of the regions. In particular, investors prepare projects in which information about the specifics of their activities and their impact on the environment should be stated.

Owing to the poor state policy at the regional and local levels, there is the lack of funds in the local budgets for performing work connected with the development of urban planning documentation, which is extremely unprofitable for the state.

It is worth emphasizing that consolidating the status of local authorities at the legislative level, providing them with independence in the formation of local budgets and expanding their scope of competencies gradually contributes to the development of local self-government. In particular, in the process of forming regional policy the leading place is taken by cross-border cooperation. In this regard, new opportunities are opening up for enhancing economic activity in the peripheral territories and increasing their competitiveness by mobilizing the natural resource potential of the neighboring territories. Cross-border cooperation is regulated by the Law of Ukraine «On Cross-Border Cooperation» and a number of regulatory acts. The spatial arrangement of the cross-border region is carried out in accordance with the main provisions of the laws of Ukraine «On the General Planning Scheme of the Territory of Ukraine» and «On Planning and Building Development of Territories». Yet it is also regulated by international acts, in particular: the European Convention on the Basic Principles of Cross-Border Cooperation between Territorial Communities or Authorities (1980); two more ratified protocols - the Additional Protocol and Protocol No. 2 to this Convention; «On the Ratification of the Convention on Environmental Impact Assessment in a Transboundary Context»;

${ }^{20}$ Державна стратегія регіонального розвитку на період до 2020 року. Постановою Кабінету Міністрів України від 06 серпня 2014 року № 385. URL: https://zakon.rada.gov.ua/ laws/show/385-2014-\%D0\%BF. 
«On Ukraine's Accession to the Convention on the Protection and Use of Transboundary Watercourses and International Lakes»; «On Accession to the European Charter of Local Self-Government», etc.

A significant part of the legislative base of Ukraine regarding crossborder cooperation is formed by interstate agreements of good neighborliness and cooperation, in which separate articles stipulate the development of cross-border cooperation, or intergovernmental agreements on cooperation between the border regions of Ukraine and the administrative-territorial units of the neighboring states. Today, all regions of Ukraine have concluded cross-border agreements on cooperation with the neighboring territories of the neighboring countries.

At the moment, an important role in the formation of state regional policy is played by the local authorities. It is due to the development of local selfgovernment in Ukraine that cross-border cooperation with individual cities and regions is possible. Here is brief information about the current content of the institution of local self-government in Ukraine.

The constitutional content of the institution of local self-government has two characteristics. The first is the independence of the territorial community, local authorities in solving a certain range of issues. The second - the local self-government deals with not only issues of public life, but also with matters of local importance, that is, those that are primarily related to the life of territorial communities. The list of such issues is defined in the Constitution of Ukraine and the Law of Ukraine «On Local SelfGovernment in Ukraine» ${ }^{21}$.

It is appropriate to consider the essence of local self-government through the prism of two main theories: the communal (municipal) theory, which stands for the independence of local self-government from the state, and the state theory, which defines local self-government as a form of exercising state power locally. These theories became the basis for the formation of two most common models of local self-government: Anglo-Saxon (the local authorities are autonomous in relation to state power) and continental (both local self-government and state administration are combined at the local level). Each of the theories of local self-government has its advantages and disadvantages ${ }^{22}$.

However, it should be noted that local affairs can only be administered if there are appropriate rights, arising from the public nature of the activities

${ }^{21}$ Рішення Конституційного Суду України у справі за конституційним поданням Міністерства внутрішніх справ України щодо офіційного тлумачення положення частини другої статті 28 Закону України «Про статус депутатів місцевих Рад народних депутатів» (справа про охорону трудових прав депутатів місцевих рад від 26 березня 2002 року № 1-9/2002). URL: http://zakon.rada.gov.ua/laws/show/v006p710-02. 2017

${ }^{22}$ Слесар К. Теорії та моделі місцевого самоврядування. URL: https://naub.oa.edu.ua/ 
of the population, the bodies and officials elected by it, that act in the interests of society with certain obligations ${ }^{23}$.

A. Batanov stresses: «the member states of the Council of Europe, which signed the European Charter on Local Self-Government, proceeded from the fact that «the existence of local authorities endowed with real powers can ensure the administration which is effective and close to citizens» (the preamble of the European Charter on Local Self-Government). We are talking about the activities of the individual elements that make up the mechanism of the local self-government (local government bodies and officials, territory, regulatory legal acts, communal property, etc.), as well as the focused activities of the entire socio-political system of society and democratic statehood as a whole, which comes down to solving important problems and achieving global goals that arise in a given historical period in society and the state in general ${ }^{24}$.

Addressing the issues of global importance begins at the local level. In particular, the UN Vienna Declaration on the Right to Development, $1986^{25}$ recognizes that a person must be an active participant and beneficiary of the right to development. The European Declaration of Urban Rights, adopted by the Permanent Conference of Local and Regional Authorities of Europe (CLRAE) of the Council of Europe 1992, states that residents of European cities, being aware of their responsibility for the condition of cities, show solidarity and commit themselves to ensuring for all residents of cities equal rights to legal safety, environmental safety, the opportunity to find work and thereby ensure their personal financial independence, housing, safe traffic, health protection, sports and recreation, the possibility to be engaged in a variety of cultural and creative activities, the peaceful coexistence of various cultural, ethnic and religious communities, quality architecture, a harmonious life, their personal political life, economic development, harmonious development (when the local authorities strive to achieve a balance between the economic development and environmental protection), a wide range of goods and services, the rational use of natural resources, cooperation between cities, financial security, equality of all citizens independently of gender, age, religion, material and political status, physical or mental impairments ${ }^{26}$.

${ }^{23}$ Яворський В. Д. Основні напрямки удосконалення законодавства про місцеві вибори в Україні. Державне будівництво та місцеве самоврядування: зб. наук. пр. 2001. Вип. 1. С. 119-124.

${ }^{24}$ Батанов О.В. Принципи місцевого самоврядування як ціннісний вимір муніципального права та сучасного муніципалізму в Україні. Вісник Дніпропетровського університету імені Альфреда Нобеля : Серія «Юридичні науки». № 1(2). 2012. С. 61-66.

${ }^{25}$ Декларація про право на розвиток» 1986 URL: http://zakon3.rada.gov.ua/laws/ show/995_301.

${ }^{26}$ Свропейська декларація прав міст. URL: http://www.eru.org.ua/index.php?page=1206. 192 
It is no coincidence that the United Nations Conference on Environment and Development, held up to the mark in June 1992 in Rio de Janeiro (Brazil), showed that the state of the environment is one of the most important factors of global, regional and national security ${ }^{27}$. The basic provisions for addressing sustainable environmental management are the principles set forth in the Declaration on Environment and Development endorsed at the United Nations Conference (Rio de Janeiro, 1992).

At the same time, the involvement in solving local issues is voluntary. This is evidenced by the signed Additional Protocol to the European Charter of Local Self-Government on behalf of Ukraine of October 20, 2011 (adopted by the Parliament on September 2, 2014). The Additional Protocol to the European Charter of Local Self-Government significantly expands the rights of citizens to participation in the affairs of the local authorities, it contains a warning against bribery or the use of force or forced forms of participation of a person in the public life of local communities. The signing of the Additional Protocol, its implementation in the national legislation and the practical application of the standards envisaged therein will contribute to the democratization of society.

Nevertheless, there are a number of unresolved issues of local (municipal) democracy, which leave an imprint within the context of the initiated and quasi-implemented in Ukraine - constitutional, administrative, educational, medical, public administration reforms and other reforms. A reform which is considered to be successfully implemented is the one that is applied in reality at the local level and is positive for the individual and citizen.

Particularly, the development of urban planning documentation is extremely important for the implementation of state environmental policy at the local level, it is normative in nature and is adopted on the basis of legislation and by-laws of the executive authorities in order to ensure an appropriate social result. This act establishes not only a map of the city with streets, but it should also take into account important environmental components for the safe and healthy living of the residents - the city's community. Solving the problems of the life of society or the so-called issues of local importance determines the municipal sociality. The implementation of local democracy is the fundamental grounds for a democratic political regime of a state. Local democracy is a teleological reference point for the existence of municipalism, the local community, and the individual ${ }^{28}$.

\footnotetext{
${ }^{27}$ Хилько М. І. Екологічна безпека України: Навчальний посібник. К. 2017. С. 37.

${ }^{28}$ Петрецька H.I. Забезпечення права на екологічну безпеку громади під час розроблення містобудівної документації. Матеріали міжнародної науково-практичної конференції «Конституційно-правове будівництво на зламі епох: пошуки оптимальних моделей», м. Ужгород, 3-4 травня 2019 р. Ужгород: Ужгородський національний університет, 2019. 310 с.
} 
Urban planning documentation is the basis of the master plan of the settlement and, accordingly, the general planning scheme of the territory of Ukraine. Issues related to urban planning documentation, that is, approved textual and graphic materials on the regulation of planning, development and other use of territories, are extremely complex. The planning and zoning of the territory play an important role in the development of urban planning documentation $^{29}$.

When the plan of the territory is being designed the mutual consent in state, public and private interests is required during planning and developing the territories, which also includes: the identification and rational mutual arrangement of residential and public development zones, industrial, recreational, environmental, wellness, historical and cultural zones and objects; the conservation, creation and restoration of recreational, environmental, wellness areas and objects, landscapes, forests, parks, squares, separate green spaces ${ }^{30}$.

Speaking about the unification of territorial communities and issues arising in the course of exercising powers by their bodies and officials in the newly formed communities, the cornerstone is the division of objects under jurisdiction between public authorities and local administrations. And this is also the peculiarity of carrying out public policy and the strategy both at the national and regional levels. It is impossible to further develop the state without realizing the need to bring the decentralization process in Ukraine to its logical end.

The accession of Ukraine and its regions to the pan-European process of regionalization requires from the country the application of regional development mechanisms whose contents are similar to those used in European countries and, above all, the implementation of program-targeted approaches. Despite their diversity, their main feature is that they organize participation and unite the efforts of various levels of government in regional development. Of particular importance are the processes of using «eco-marketing» relations in the field of environmental policy ${ }^{31}$.

The challenging issue is to rebuild the development strategy of the state in order to overcome the complex crisis phenomena and finally get rid of the status of a transition state. The point is that it is necessary to develop cities and regions which, in the territorial sense, constitute the state. Each region of our state is special in terms of environmental management. The legislation regulates various guarantees of the right to general (public) use of natural resources, however, it should be noted that recently, with the development

${ }^{29}$ Про регулювання містобудівної діяльності. Закон України. Відомості Верховної Ради України. 2011. № 34. Ст.343. URL: https://zakon.rada.gov.ua/laws/show/3038-17.

${ }^{30}$ Ibid.

${ }^{31}$ Крук В.Ю. Екологічна політика України: сучасний стан та перспективи розвитку (регіональний аспект). Актуальні проблеми державного управління: зб. наук. праць. ОРІДУ. О. 2006. Вип. 2(26). С. 264-270. 
of market relations, the emergence of multi-entity ownership of land, water bodies, forests, this human right, has, unfortunately, been narrowed. Based on the analysis of Art. 22 of the Constitution of Ukraine the right to use natural resources is guaranteed, whereas narrowing the content and scope of this right is not allowed ${ }^{32}$.

The general right to natural resource use, established by national legislation, is based on the principles of environmental law, which in its turn is based on generally recognized provisions of international environmental law. The best way out of this situation is considered to be the possibility of granting public easement by state bodies and local self-government bodies, which would make it possible to better balance the interests of owners (users) of natural objects and territorial communities, and would act as a legal guarantee of ensuring the right to the common use of nature ${ }^{33}$.

Cherkashchyna M. highlights that the public easement law on nature use has features that correspond to the rights of citizens to a safe environment, to the exercise of the right to general use of natural resources to the extent determined by resource legislation. This opinion cannot be rejected and we believe that in the development of urban planning documentation such easements should be marked. It is close to impossible that regional and local policies can develop without the proper territory planning.

\section{SUMMARY}

Modern scholars distinguish three main levels in the implementation of environmental policy: global, national and local. Contemporary environmental policy, both at national and regional levels, is developed and implemented under tense political conditions which are caused by various political goals and interests of agencies and this often leads to conflicts between individuals within society; this concerns the issues of natural resources use by public, the distribution of economic requirements and costs, the responsibility for environmental crimes and their consequences.

The approval of the national development strategy requires good public management in all sectors of the economy, levels of government in order to form an ecological culture, change the communication and information sphere, political, economic, social spheres in line with the priority of interests and needs from local communities to the state as a whole; it is important that environmental taxes be used only for stabilizing and solving environmental problems. A number of constitutional rights, especially the right to truthful and reliable information about the state of the environment are to be ensured.

\footnotetext{
${ }^{32}$ Конституція України: Відомості Верховної Ради України. від 28.06.1996. № 254к/96-ВР. № 30, ст. 141.

33 Черкащина М.К. Юридичні гарантії права природокористування. За ред. проф. А.П. Гетьмана. Монографія. Харків: Вид. «ФІНН», 2010. 176 с.
} 


\section{REFERENCES}

1. Національна екологічна політика: міністерство екології та природних ресурсів. URL: https://menr.gov.ua/timeline/Nacionalna-ekologichnapolitika.html.

2. Реалізація права на безпечне для життя і здоров'я довкілля в Україні: монографія. Л.Б. Васильчук, Ю.М. Бисага. Ужгород, 2019. 208 с.

3. Костицький В.В. Екологія перехідного періоду: право, держава, економіка (економіко-правовий механізм охорони навколишнього природного середовища в Україні). К. ІЗП і ПЗ, 2003. 772 с.

4. Лазор О.Я. Адміністративно-правові засади державного управління у сфері реалізації екологічної політики в Україні. Автореферат дисертації на здобуття наукового ступеня доктора наук 3 державного управління. К. 2004. ст. 8-9.

5. Національна екологічна політика: міністерство екології та природних pecypciв. URL: https://menr.gov.ua/timeline/Nacionalna-ekologichnapolitika.html.

6. Андрейцев B.I. Політика. Інновації. Приватизація. Еколологічна безпека. Право. К. 1996. С. 5-6.

7. Екологічне право: підручник. За ред. А. П. Гетьмана. Х.: Право. 2014. $432 \mathrm{c}$.

8. Заржицький О.С. Актуальні проблеми правового забезпечення екологічної політики України (теоретичні аспекти). Монографія. Д.: Національний гірничий університет, 2012. 200 с.

9.Фріб М. Як осмислити посткомунізм? Політична думка. 1997. № 4. C. $109-110$.

10. URL: https://freedomhouse.org/report-types/nations-transit.

11. URL:https://freedomhouse.org/report/freedom-world/2019/ukraine.

12. Про засади державної регіональної політики. Закон України від 05.02.2015 р. № 156-VIII. Відомості Верховної Ради України. 2015. № 13. Ст. 90.

13. Рішення Конституційного Суду України у справі за конституційним поданням Міністерства внутрішніх справ України щодо офіційного тлумачення положення частини другої статті 28 Закону України «Про статус депутатів місцевих Рад народних депутатів» (справа про охорону трудових прав депутатів місцевих рад від 26 березня 2002 року № 1-9/2002). URL: http://zakon.rada.gov.ua/laws/show/v006p710-02.

14. Слесар. К. Теорії та моделі місцевого самоврядування. URL: https://naub.oa.edu.ua/2017.

15. Яворський В. Д. Основні напрямки удосконалення законодавства про місцеві вибори в Україні. Державне будівництво та місцеве самоврядування: зб. наук. пр. 2001. Вип. 1. С. 119-124.

16. Батанов О.В. Принципи місцевого самоврядування як ціннісний вимір муніципального права та сучасного муніципалізму в Україні. 
Вісник Дніпропетровського університету імені Альфреда Нобеля : Серія «Юридичні науки». № 1(2). 2012. С. 61-66.

17. Декларація про право на розвиток» 1986 URL: http://zakon3.rada.gov.ua/laws/show/995_301.

18. Європейська декларація прав міст. URL: http://www.eru.org.ua/index.php?page=1206.

19. Хилько М. І. Екологічна безпека України: Навчальний посібник. К. 2017. 266 c.

20. Петрецька Н.I. Забезпечення права на екологічну безпеку громади під час розроблення містобудівної документації. Матеріали міжнародної науково-практичної конференції «Конституційно-правове будівництво на зламі епох: пошуки оптимальних моделей», м. Ужгород, 3-4 травня 2019 р. Ужгород: Ужгородський національний університет, 2019. $310 \mathrm{c}$.

21. Про регулювання містобудівної діяльності. Закон України. Відомості Верховної Ради України. 2011. № 34. Ст. 343.

22. Крук В.Ю. Екологічна політика України: сучасний стан та перспективи розвитку (регіональний аспект). Актуальні проблеми державного управління: зб. наук. праць. ОРІДУ. О. 2006. Вип. 2(26). C. 264-270.

23. Конституція України: Відомості Верховної Ради України. від 28.06.1996. № 254к/96-ВР. № 30. Ст. 141.

24. Черкащина М.К. Юридичні гарантії права природокористування. За ред. проф. А.П. Гетьмана. Монографія. Харків: Вид. «ФІНН», 2010. $176 \mathrm{c}$.

25. Скрипчук П.М., Строченко Н.І., Вега А.Ю. Соціо-екологоекономічні засади природокористування: інновації, інвестиції та механізм реалізації. Монографія під редакцією Скрипчука П.М. Рівне: НУВГП, 2014. 454 с.

26. Про Основні засади (стратегію) державної екологічної політики України на період до 2020 року. Закон України від 21.12. 2010. № 2818-VI. Відомості Верховної Ради України. 2011. № 26. Ст. 218.

\section{Information about the author:}

Petretska N. I.,

Candidate of Law, Associate Professor at the Department of Constitutional and Comparative Law, Uzhhorod National University 26, Kapitulna str., Uzhgorod, 88000, Ukraine 